\title{
IR THEORY AS AN 'ARELIGIOUS' RESEARCH FIELD: THE SOURCES OF AND CRITICAL PROSPECTS TO OVERCOME THE INTELLECTUAL FAILURE
}

\author{
İ. Erkam SULA * \\ Çağla LÜLECÍ $\dot{~}^{*}$
}

\begin{abstract}
This study is built on an observation that 'religion' along with many other factors has a significant impact on international relations. However, religious factors are not incorporated in International Relations (IR) theoretical analysis. Hence, it is deemed necessary to ask: 'When did IR scholars lose the track of religion in their theories and how to bring religion back in?' An answer is provided through an analysis of the literature to find out the sources of such neglect and possible ways to overcome it. The study does so in two parts. First, it is argued that the adoption of natural sciences' methodology in IR- the so-called 'Behavioralist revolution'- has been quite influential in the lack of interest on religion. Secularism has been an unquestioned part of Behavioralism - the 'positive science' update package adopted by scholars of IR theory. The end of the Cold War brought ideational variables back in to the study of IR theory. This process is directed mainly by the emergent 'Critical', 'Constructivist' or 'postpositivist' turn in IR. Therefore, the second part focuses on the critical approaches to IR theory in the post-Cold War era with a specific focus on Critical Theory (CT) in order to develop a possible way to incorporate religion in IR theoretical analysis.
\end{abstract}

Keywords: Religion, International Relations Theory, Behavioralism, Critical Theory, Secularism.

JEL Classification: Z00

* Corresponding Author. Department of International Relations, Bilkent University; Department of International Relations, Yildirim Beyazit University, Ankara, Turkey. sula@bilkent.edu.tr

** Department of International Relations, Bilkent University; Department of Political Science and International Relations, Ted University, Ankara, Turkey. cagla.luleci@bilkent.edu.tr 


\title{
BİR ENTELEKTÜEL BAŞARISIZLIĞIN KÖKENLERİ VE MUHTEMEL ELEŞTİREL ÇÖZÜMLERİ: ‘DINDIŞI’ BİR ARAŞTIRMA ALANI OLARAK ULUSLARARASI İLIŞKILLER KURAMI
}

\begin{abstract}
Özet
Bu çalışma, dinin uluslararası ilişkilerde başka birçok faktör gibi önemli bir etkisi olduğu gözlemine dayanmaktadır. Buna rağmen dini faktörler Uluslararası İlişkiler kuramı analizlerine çok fazla dâhil edilmemektedir. Bu durum "Uluslararası İlişkiler öğrencileri kuramlarında din faktörünü dikkate almayı ne zaman bırakmıştır ve dini Uluslararası İlişkiler kuramlarına geri getirmek nasıl mümkün olabilir?" sorularını sormayı gerekli kılmaktadır. Bu çalışmada bahsi geçen soruya cevap, iddia edilen ihmalin kaynaklarını bulmak ve çözüm önerileri sunmak amacıyla literatürü gözden geçirmek yoluyla verilmektedir. Çalışma bunu iki bölümde yapmaktadır. Çalışma öncelikle "Uluslararası İlişkilerin doğa bilimleri yöntemini benimsemesi, yani 'davranışsal devrim' dine olan ilginin azalmasında etkili olmuştur” iddiasını tartışmaktadır. Sekülerlik, davranışsalcı literatür tarafından 'pozitifbilim güncelleme paketi’ ile gelen bir yenilik olarak fazla sorgulanmadan kabul edilmiştir. Çalışmanın ikinci bölümü Soğuk Savaş sonrasında Uluslararası İlişkiler kuramına eleştirel yaklaşımlara, özel olarak da Eleştirel Kuram tartışmalarına odaklanmakta ve dini Uluslararası İlişkiler kuramı analizlerine yeniden dâhil etmenin olası yollarını tartışmaktadır. Bunun sebebi, Soğuk Savaş่ın sonunun düşünsel değişkenleri Uluslararası İlişkiler kuramına geri getirdiği iddiasıdır. Bu süreç de uluslararası ilişkilerdeki "eleştirel/ inşacı/post-pozitivist" dönüşüm ile yakından ilgilidir.
\end{abstract}

Anahtar kelimeler: : Din, Uluslararası İlişkiler Kuramı, Davranışsalcılık, Eleştirel Kuram, Sekülerizm

JEL Sınıflaması: Z00

\section{Introduction}

This study is built on an assumption that 'religion' along with many other economic, cultural or political factors has an impact on international relations. However, neither positivist theories that aim to build causal relations between variables, nor critical theories that aim to understand the world without establishing explanatory arguments have managed to integrate religion as an influential factor into their studies on world politics. Put it differently, theories of International Relations (IR) do not directly count religious factors among major components of their analysis. Hence, it is deemed necessary to ask: 'When did IR theory scholars lose the track of religion and how could we incorporate religion within IR theory?' An answer is provided through a detailed analysis of the literature to find out the sources of such neglect and possible ways to overcome it. The study first argues that the adoption of natural sciences' methodology in IR in the late 1950s with the so-called 'behavioralist revolution' has been influential in the lack of interest on religion. Secularism remains to be an unquestioned part of behavioralism - the 'positive science' update package adopted by scholars of IR theory. 
As the literature almost agrees upon, the end of the Cold War brought ideational variables back into the study of IR theory. Critical, constructivist, or post-positivist turn in IR created opportunities for the integration of non-material factors into the study of world politics. Critical theorists, with their emphasis on the interrelationship between theory and practice, have offered an alternative way of theorizing in IR and emphasized the importance of the historical, social and political context within which a theory is built. Hence, while taking critical approaches to IR as a starting point, this study secondly argues that understanding the criticism that is provided by the Critical Theory of IR could be a useful way to 'bring religion back in' the field of IR theory and to deconstruct the misunderstanding of the 'secular study' of world politics.

The study develops this two-faceted argument in two separate parts. The first part specifically deals with the behavioralist-traditionalist debate or the so-called second great debate in IR theory and its connection with secularism in IR theory throughout the Cold War. ${ }^{1}$ The second part deals with Critical Theory as one of the most influential critical approaches to IR in order to develop a possible way to incorporate religion in theoretical analysis. Accordingly it generates a set of research questions to be asked by a Critical Theory perspective focusing on the role of religion in IR. Finally, the study concludes with a summary of the main argument and shows directions for possible further research.

\section{The Origins of Areligious IR Theory}

Any analysis of the history of science reveal that scientists/ philosophers had for a long time tried to find out reasons for the events with reference to religion. ${ }^{2}$ Inspired by such reference, at least from the medieval ages onwards (if not from before) human beings had been seen at the center of the universe and everything was expected to be at the service of the human. Let's take astronomy as an example. According to Burtt ${ }^{3}$ with the exception of a few brave but scattered thinkers, "the legitimacy of selecting some other point of reference in astronomy than the earth had never suggested itself to anyone." Therefore most of the discoveries that diminished the central importance of 'men's world' were regarded as challenges to religion. That is why Copernicus' claim that world is not at the center and Galileo's support for his 'heliocentric claim' were regarded as heresy and trialed by the church.

1 We do not argue that religion is fully ignored in the study of international relations. For instance, there are studies that focus on the role of religion in decision making processes (See: S. Güner, "Religion and Preferences: A Decisiontheoretic Explanation of Turkey's New Foreign Policy”, Foreign Policy Analysis, 8(3), 2012, pp. 217-230.) Rather, what we argue in this study is that religion is not sufficiently taken into account while theorizing IR.

2 Such reference was closely related with the studies of Astronomy. Hannam (2009: 370) gives an interesting account of how scientific discoveries were regarded as religious omen. For instance, the appearance of "Halley's Comet" in 1456, was interpreted as a godly sign that a catastrophe (the invasion of Turkish armies) was near. It is even rumored that the then pope Callistus III had excommunicated the "Halley's Commet" a desperate measure against what he regarded as 'heresy'.

3 E. A. Burtt, The Metaphysical Foundations of the Modern Science, New York, Dover Publications, 2003 , p. 19. 
Any idea that challenged the long-accepted metaphysical, mythological and magical explanations of the church was to be trialed and stopped. As such discoveries and church pressure have continued, the idea of secularism in science gained more and more prominence. Therefore, a 'secular' science, the idea that science should be separated from religion, is not a brand new one. Though not easy to locate its 'Big Bang,' one can refer to the so- called scientific revolution and the age of Enlightenment of the early modern period as the time when such idea was crystallized. As the $15^{\text {th }}, 16^{\text {th }}$ and $17^{\text {th }}$ centuries went on, the scientific methods of observation and questioning have replaced metaphysics, mythology and magic. Science was to show how things worked but not who created them. Hence, a belief in divine authority was replaced by a belief in human capacity to reason ${ }^{4}$.

It might be argued that the Enlightenment belief in the human capacity to reason turned into a human capacity to control as people aimed to observe, find out causal mechanisms that would lead to generalizations which in turn might help them predict what would happen in the future. As the belief on the possibility of generalization and prediction increased, so did the belief in human capacity to control. These ideas might have led philosophers to leave the non-predictable, value and normativity oriented religious beliefs, in order to search for unchanging patterns that are explained in a value-free, objective and generalizable manner. Science, after all, was not to understand how and why things are created or who created them but it was to explain how things worked and by doing so decrease the uncertainty of the future and increase predictability and possibility to control it ${ }^{5}$.

The idea of value-free, positive science emerged out of this trend. It was August Comte in his famous description of three stages of knowledge -the theological stage, the metaphysical stage and the positive stage- who applied such understanding to the epistemology of social science in his series of writings The Course in Positivist Philosophy (Cours de Philosophie Positive). In the theological stage everything is explained with reference to God. Phenomena is created and controlled by God. This stage "regards the facts of the universe as governed not by invariable laws of sequence, but by single and direct volitions of beings..."'. In this stage world is believed to be governed by a single concrete God. Indeed, this resembles the mode of thought in the preenlightenment era. The second stage is the extension of the first in which there is no concrete god

4 See Burtt, Ibid.; James Hannam, God's Philosophers: How the Medieval World Laid the Foundations of the Modern Science, London, Icon Books, 2009.

5 In fact it is ironic that those who argued for the rejection of religious explanations to phenomena have developed an alternative belief system that develops its own dogma. For instance, when we say "the belief in human capacity to reason" we implicitly argue that an alternative belief system has been developed by those philosophers. One might argue that such a powerful belief in human capacity to reason and/or control, the possibility to predict the future, the possibility of finding unchanging patterns of causality might create an alternative 'normativity' which in its own rights is not much different from religious dogma. Since when a belief is that powerful, it would inevitably lead people reject alternative visions. By this way, one might argue that the idea of Positive science has been a 'religion that rejects religious explanations' but of course this is a topic for another paper.

6 John Stuart Mill, Auguste Comte and Positivism, London, N. Trübner, 1856, p. 5.; See also Daniel Philpott, “The Challenge of September 11 to Secularism in International Relations”, World Politics, 2002, 55(1), p. 66-95. 
but metaphysical and abstract forces that govern the world. The final positive stage refers to the knowledge that is generated through scientific methods of observation and experiment. At this stage people do not explain phenomena with reference to metaphysics or a god but they explain it through the scientific method that looks for cause and effect relationships among observable phenomena.

Indeed, the belief in the human capacity to reason and its impact on the development of 'positive science' gained resemblance in the ideas of the later philosophers. The rejection of religion as a source of explanation that emerged in the age of Enlightenment has first gained prominence in natural sciences and then applied to social sciences as well. When IR studies started to consider these philosophical issues in the late 1950s, the idea that religion has to be pushed to the private life of people and that it has no place in scientific explanation had already been established in social theory. What IR theoreticians did, in fact, was to adopt the so-called behavioral revolution in social theory, sociology and political science as an unquestioned 'upgrade package.' Hence, religion did not become even part of the first important major philosophical debate that took place among the then proponents of IR theory ${ }^{7}$. This claim is indirectly proven by the fact that neither Kaplan ${ }^{8}$ who represents the behavioralist camp, nor Bull ${ }^{9}$ who represents the traditionalist camp, do mention religion in their debate. Indeed, one might argue that religion had not been a topic debated especially in IR theorizing. The traditionalist- behavioralist debate was about the method that is to be used by IR theories. And since IR theories adopt its methodology from social and political science, the students of IR have unconsciously disregarded religion which -as we would argue- is a very important variable in IR.

Fox ${ }^{10}$ provides an alternative vision on this issue. He mentions that in the $20^{\text {th }}$ Century, theories of modernization and secularization focusing on studies of Marx, Mill, Weber, Freud, Comte, and Durkheim have argued that religion's role in human life, and in natural and social sciences is in decline. According to what they argued, as modernization gained pace religion would lose its significance. The modern state would develop secular systems of governance that do not resort to religion as a source of legitimacy and social order, and as urbanization, universal education and literacy takes place religion would be pushed to the private lives of the people and at best be in decline if not completely removed from politics. As Fox ${ }^{11}$ argues, this was a general trend in the $20^{\text {th }}$ Century social sciences and there are exceptions to such an argumentation. But it was not until 1980-90s that proponents of political science and sociology have started to question such

7 Here we are not talking about major IR debates in general but specifically with the ones related to metatheory. There have been two general meta-theoretical debates in IR one between traditionalism vs. behavioralism and the other between rationalist vs. reflectivist or positivist vs. post-positivist theories.

8 Morton A. Kaplan, “The New Great Debate: Traditionalism vs. Science in International Relations”, World Politics, 1966, 19(1), p. 1-20.

9 Hedley Bull, "International Theory: The Case for a Classical Approach", World Politics, 1966, 18(3), p. 361-377.

10 Jonathan Fox, The Multiple Impacts of Religion on International Relations: Perceptions and Reality in Religion and International Relations, 2006, http://www.cairn-int.info/article-E_PE_064_1059--the-multiple-impacts-ofreligion-on.htm (03.09.2015).

11 Fox, Ibid., p. 3. 
a trend. For IR the situation is even worse. Somehow, IR scholars have taken the insignificance and non-observability of religion as granted and fixed. IR scholarship can be said "to have more profoundly rejected religion than the other social sciences." ${ }^{12}$ Fox claims that this is so because IR has been a Western discipline that is developed on the national security studies of the Cold War era. The Cold War era was an era of ideological competition that did not have religion among its major determinants. Another reason is that the nation state system was based on the treaty of Westphalia which is argued to end religious international wars. Since then religion was not taken as a significant determinant of international relations ${ }^{13}$.

Indeed IR theory was inarguably one of the disciplines that suffered from the Cold War rivalry. The period was of high nuclear rivalry risking MAD (Mutually Assured Destruction) so that controlling and predicting the future became an obsession for strategic studies and the proponents of IR theory. Theories that focus on 'low politics' (culture, identity, social relations) have been pushed in the margins of the discipline while most IR theories focused on the bipolar international structure, strategic interaction among the two camps, the role of international institutions in maintaining peace whereas disregarded identity, culture which became more prominent only after the dissolution of the Soviet Union. Under such circumstances it is understandable that IR theories did not take religion into account whereas its proponents focused on human capacity to predict and control its own future, to avoid nuclear disaster. Though one may argue that there had been several issues of world politics during the Cold War which included religion as a significant factor such as the Israeli-Palestinian conflict, or Soviet invasion of Afghanistan, it is not really surprising that they remained underemphasized when it comes to theorizing in IR. Theoretical debates of the Cold War era (if one considers traditionalist-behavioralist debate as a meta-theoretical one) focused mostly on great power politics. The questions at hand were the ones related with war, peace, deterrence, power, polarity, and the structure of the era, and rational calculations related with cooperation and conflict. IR theory of the time seems to be what 'the gate keepers' located mainly the Western academia thought it was.

When we understand theory within its context the reason behind the neglect of religion can be related to the Cold War era. But international relations (though not as a separate discipline) or inter-state relations had been in place since Westphalia (if not before). Let us accept that the Cold War caused neglect of religion, but what about the previous era? What happened between 1648 and 1900s? ${ }^{14}$ What kind of IR theories existed and did they consider religion as a variable in International relations? These questions still remain unanswered by the literature on IR theory.

12 Fox, Ibid., p. 3.

13 Nükhet Ahu Sandal and Jonathan Fox, Religion in International Relations Theory: Interactions and Possibilities, New York, Routledge, 2013.

14 It is important to note here that the first "IR" department (and IR as a distinct discipline) is founded in 1919 at the Woodrow Wilson Chair at Aberystwyth, University of Wales. Establishment of the theory of IR, as we know it today, took place later on. Before then, IR had been studied as a sub-field or an issue under the political science discipline. Yet we still face the question: what would be the main venues of political science in taking religion into analyses? The answer to this question would also partially make an answer to the roots of the neglect of religion in IR theory. These questions offer a probable direction for further research. 
Whatever happened in the pre-Cold War or in the Cold War era had important implications on the development of the discipline. Religion did not seem to be part of mainstream IR theoretical explanations. This is not so because the theories are anti-religious but instead they are 'areligious' meaning that they are not against religion but they simply did not consider it as a variable, a factor, or a determinant. With the end of the Cold War the use of ideational variables in theoretical explanations became more prominent and recent attempts have tried to deal with the issue of religion and IR theory ${ }^{15}$. It was only by the end of the Cold War that some IR scholars have tried to bring religion back in, an issue that will be dealt with in the next part $^{16}$.

\section{Bringing Religion Back in: Possible Contributions of Critical Theory}

Since the behavioral revolution of 1950-60s in the U.S. academia, IR has become increasingly dominated by approaches that accepted the unity of scientific methods and accordingly tried to apply the methods of natural sciences to the social sciences. With the wide adoption of positivism in IR, scholars have argued for the application of scientific rules such as falsification, parsimony, objective engagement to theorizing and focused specifically on quantitative methods in IR. For instance, Waltz was also inspired from the move towards the scientific tradition and applied his own understanding of the contemporary philosophy of social sciences ${ }^{17}$ and structural realism became one of the most dominant approaches to the study of IR.

Although the positivist theories dominated the discipline (especially in the U.S.) an important approach to the study of international politics was also developing at the same time in Europe: the Marxist theories of Frankfurt School ${ }^{18}$. The dominance of the realist approaches on the one hand and the dominance of the positivist approaches on the other have led some scholars to follow a neo-Marxist and/or post-positivist approach to the study of world politics. Especially in the 1980s, inspired from the emancipatory approach of Marxism, a critical approach to international relations began to emerge within the discipline ${ }^{19}$.

15 See E. S. Hurd, “The Political Authority of Secularism in International Relations”, European Journal of International Relations, 2004, 10(2), p. 235-62; Jonathan Fox and Shmuel Sandler, Bringing Religion into International Relations, New York, Palgrave-Macmillan, 2004.; Nükhet Ahu Sandal and Patrick James, "Religion and International Relations Theory: Towards a Mutual Understanding”, European Journal of International Relations, 2011, 17(1), p. 3-25; Jack Snyder, Religion and International Relations Theory, New York, Columbia University Press, 2012.

16 It appears as if IR theory is following the trends in social theory, political science and sociology from some decades behind. First they develop arguments against secularism, secular science and then IR studies start to consider it. The discipline seems to be 'derivative' rather than having an independent character. This is probably another reason why religion was not considered in philosophical debates of IR in the first place.

17 Nicholas Rengger and Ben Thirkell-White, "Still Critical After all These Years? The Past the Present and Future of Critical Theory in International Relations", Review of International Studies, 2007, 33, p. 3-4.

18 Rengger and Thirkell-White, Ibid., p. 4.

19 See Robert Cox, "Social Forces, States and World Orders: Beyond International Relations Theory", Millennium: Journal of International Studies, 1981, 10(2), p. 126-55.; Richard K. Ashley, "Political Realism and Human Interest", International Studies Quarterly, 1981, 25, p. 204-236.; Andrew Linklater, "The Achievements of Critical Theory", International Theory, Eds: S. Smith, K. Booth, and M. Zalewski, Cambridge, Cambridge University Press, 1996, pp. 
Critical Theory has thrown a serious blow to the methodologies of and the issues that are studied by mainstream IR theory. The theoretical momentum that is gained through Critical Theory's emphasis on theory/practice relationship, historical sociology, discourse ethics, and the value driven nature of theorizing could be utilized in a fruitful way to overcome the areligious nature of IR theories. Critical Theory provides a prospect for new research based on specific religion-IR theory research questions that are based on its core arguments. This part, in general, explores ways to utilize such prospect ${ }^{20}$.

Two articles that were published in 1981, one by Robert $\operatorname{Cox}^{21}$ and the other by Richard Ashley ${ }^{22}$, were generally referred to as the founding texts of Critical Theory. Although critical approaches have taken many forms after the publication of these articles, most of the arguments were mainly developed on the foundation provided by Cox and Ashley. One of the main points of Critical Theory ${ }^{23}$ is that it always distinguishes itself from "other forms of theorizing in terms of its orientation towards change and the possibility of futures that do not reproduce the patterns of hegemonic power of the present" ${ }^{24}$. They have called to rethink established modes of theorizing in IR. Following these articles Critical Theory has been developed in two ways: Cox's Marxian inspired search for "the counter-hegemonic structures" which was based on the empirical method of "historical sociology" and Ashley's criticisms of structural realism inspired by Habermas' understanding of knowledge constitution ${ }^{25}$. Thus, it becomes useful to analyze main arguments of Critical Theory and to pose certain internal critiques to them in order to find out a list of questions that could be utilized to incorporate religion within critical analysis and IR theory.

Critical Theory Argument 1 - "Theory is always for someone and for some purpose"26.

The hallmark of Robert Cox's work is the famous quote: "Theory is always for someone and for some purpose"27, which is a simple sentence that summarizes the main concern of Critical

279-298.; Kimberly Hutchings, "Happy Anniversary! Time and Critique in International Relations Theory", Review of International Studies, 2007, 33, p. 71-89.; Jurgen Habermas, Moral Consciousness and Communicative Action. Cambridge, Polity, 1990.; John M. Hobson "Is critical theory always for the white west and western imperialism? Beyond Westphilian towards a post-racist critical IR”, Review of International Studies, 2007, 33, p. 91-116.; Rengger and Thirkell-White, Ibid.

20 It is important to note here that we do not offer Critical Theory as the best or the only venue of integrating religion into IR theory. However, we argue that the contributions of Critical Theory open up a significant venue to integrate religion into IR theoretical studies.

21 Cox, Ibid.

22 Ashley, Ibid.

23 It is important to mention that critical approaches have taken diverse directions and in fact, it is not possible to talk about a homogenous body that creates a critical theory. However, the term Critical Theory will be used in the text as a framework term in order to refer to the founding arguments of the critical approaches that were laid down by Cox and Ashley.

24 Hutchings, Ibid., p. 72.

25 Hutchings, Ibid., p. 73-74.

26 Cox, Ibid., p. 128.

27 Cox, Ibid., p. 128. 
Theory ${ }^{28}$. Cox claims that there can be no objective engagement with the nature. The nature is observed through the 'value window' of the researcher. So the inquiry becomes ideologically oriented. If the nature is observed with an ideologically oriented way and values of the researcher determine the findings of the research then the questions of 'whose values?' or 'which values?' comes to place. Accordingly as Cox have claimed "If the findings of studies can vary depending on the values chosen, then the choice of a particular value system tends to empower and enfranchise certain individuals and groups while disempowering and disenfranchising others"29. Thus, theories work for 'someone and for some purpose' and theorizing becomes a 'political act.' By regarding the theorizing process as a political act, Cox emphasized the theory/practice relationship. Theory and practice are "mutually reinforcing" and both are done "for a particular practical/political interest" ${ }^{\prime 30}$. While theorizing the theorist is also engaged with practice. Without taking the theory/practice relationship into account theories can serve the perpetuation of the status-quo which, in turn, maintains the existing inequalities; but once recognized critical theories may serve to transform the existing status-quo. Such a view of theories and theorizing provides a useful opportunity to question the 'areligious' nature of IR theory in general. If theory serves the values of certain actors, then which and whose values does the ignorance of religion in $I R$ theory serve to ? $^{31}$

Critical Theory Argument 2- "If history is produced by our actions, then it should also be open to change."32

Cox based his critical understanding on the analysis of history. According to Cox, change and progress is "immanent within history" and history can either be diagnosed or made. In 'diagnostic' mode, critique identifies the potential for progress immanent in history. In 'making' mode, by acting on the potential for progress immanent in history, critique helps to bring progress about".33 If history is produced by our actions, then it should also be open to change. By providing an analysis of history, Cox has tried to show the possibility of change towards an emancipatory

28 If theories are to be understood as tools or perspectives to analyze and explain the complex phenomena in an organized manner then the meaning of the statement becomes clearer. Positivist approaches have generally claimed that theorists engage the world from an objective point of view. The scientist according to positivism should engage the research from an objective point of view and observe the reality to extract the existing causal mechanisms that exist within the nature. Thus, by engaging to the issue as an 'outsider' the researcher explains the world that exists independent of his/her personal values or character.

29 M. Griffiths, S. C. Roach, and M. S. Solomon, Fifty Key Thinkers in International Relations, London, Routledge, 2009, p. 64.; Cox, Ibid., p. 207-8.

30 Hutchings, Ibid., p. 74.

31 Some might argue that values and beliefs should be treated as separate areas of the ideational environment. Yet we argue that personal and cultural values regarding what is good, beautiful, beneficial, useful, significant, and constructive are closely related with one's beliefs and misbeliefs. Thus, for the purpose of this study, we refer values as an ideational factor in theorizing which contains beliefs and misbelief as well, rather than as something related with religion per se. In this sense, what we aim to question here is whether the ignorance of religion (as a belief system) in IR theorizing serves to certain values, or not. Though we accept that there are differences between one's values and beliefs, this might be a topic for another research, but not this one.

Cox, Ibid. 
future. He mentions that "Critical Theory is theory of history in the sense of being concerned not just with the past but with a continuing process of historical change. Problem solving theory is non-historical or ahistorical since it, in effect, posits a continuing present (...)". ${ }^{34}$ Thus problemsolving theories do not generally see the possibility of change and accept the structure as a static one. ${ }^{35}$ Such a view of history provides an important opportunity to analyze religion in international relations. If the history of IR theory is made in a way to exclude religions' impact on international politics, then is it possible to see and read it differently? If possible, then how could one offer a 'potential for progress' immanent within it?

Critical Theory Argument 3 - "People should reject all systems of inclusion and exclusion (boundedness) and enter into dialogue. No person and no moral position can be excluded in advance.".36

Cox's arguments have largely influenced the neo-Marxian critical studies literature. Linklater, in his analysis of Critical Theory, mentions that there are four main achievements of the Marxian-inspired critical theory. ${ }^{37}$ The first achievement is their emphasis on the subject/object relationship. As also mentioned above, Cox argued that there can be no objective engagement of the subject with the object of the research. That is to say, the researcher cannot find an objective reality independent of his/her values and perspectives. In other words, Marxian critical theory argues that knowledge is constructed and it, in turn, produces and reproduces certain interests "that result in unsatisfactory social outcomes." Second achievement of the critical theory is its emphasis on the possibility of change. Contrary to the arguments of the mainstream IR theories, existing social structures are not immutable or unchangeable. If the existing "unsatisfactory social structure is the product of agents then the agents are also able to transform the structure to produce a more satisfactory one. Third, according to Linklater, Critical Theory gets inspired by Marx, but following Habermas' writings on "social learning", "discourse ethics" and "boundedness", they overcome its weaknesses. ${ }^{38}$ Fourth achievement is also related with the third one. Following Habermas' claims the "critical theory judges social arrangements by their capacity to embrace open dialogue with all others" ${ }^{\prime 39}$.

In social relations people enter into bounded communities with excluding others. This boundedness has led some theories like Neorealism for instance, to argue that these bounded communities should deal with each other with military power. However, Habermas claims that there are 'forms of social learning.' In the highest level of morality they learn ethical reflectiveness. Ethical reflectiveness refers to the capacity of the agents to recognize that "moral codes are

34 Cox, Ibid., quoted in Hutchings, Ibid., p. 74.

35 This is one of the main diverging points between 'critical theories' and 'problem-solving theories'.

36 Linklater, Ibid., p. 285-290.

37 Linklater, Ibid.

38 Linklater A (1996) The Achievements of Critical Theory. In Smith S, Booth K, and Zalewski M (eds) International Theory. Cambridge: Cambridge University Press, pp. 279-298. 
malleable social products rather than immutable conventions to which they must submit" ${ }^{40}$. That there are diverse moral stand-points and none of them is more valid than others. Once reached to ethical reflectiveness, people start to reject boundedness. Thus, according to Habermas, people enter into dialogue without excluding other moral stand-points or bounded communities. This is what Habermas called 'discourse ethics.' According to discourse ethics people should reject all systems of inclusion and exclusion (boundedness) and enter into dialogue. No person and no moral position can be 'excluded in advance' 41 . Religion, as an important part of human moral codes might be incorporated in Habermasian analysis as well. Does the so-called dominance of positivism in IR theory produce a system of inclusion/exclusion in theorizing? If positivism is understood as a system of inclusion/exclusion and as a major reason behind 'areligious' IR theory can discourse ethics open up new ways in IR theory to study religion?

Critical Theory Argument 4: Structural realism's 'technical interest' in control has come to dominate classical realism's 'practical interest' of understanding during the Cold War. A reflective version of structural realism (technical realism) is needed ${ }^{42}$.

Richard Ashley, although he did not use a historical sociology understanding like Cox, has also emphasized the need for an emancipatory change in international relations. Based on his interpretation of Habermas' analysis of social learning and morality, he proposed a critique of structural realism. ${ }^{43}$ According to Ashley, 'knowledge acquisition' transcends through three interests: technical interest of control (theories of natural sciences), practical interest of understanding (theories of social sciences), and the interest of emancipation (Critical Theory). According to Ashley, structural realism's technical interest in control has come to dominate classical realism's practical interest of understanding during the Cold War. "The result is a vicious circle, in which the requirements of technical realism become built into advice about the practice of statesmanship, so that realism, in its technical form, becomes a self-fulfilling prophecy, most obviously in relation to policies of nuclear deterrence" 44 . Accordingly he called for a "reflective version of realism" which brings the main assumptions of structural realism (or technical realism as he puts it) into question. He argued for a broadening of phenomena that were considered relevant to international politics and the need for a progress towards a future that is based on emancipatory interests ${ }^{45}$. On the issue of religion a question might be posed following Ashley's perspective: Can (or should) reflective versions of realism analyze the role of religion international politics? Should religion be incorporated within it?

40 Linklater, Ibid., p. 286.

41 See Linklater, Ibid., p. 285-290.; Jurgen Habermas, Justification and Application: Remarks on Discurse Ethics, Cambridge, MIT Press, 2001.

42 Ashley, Ibid.

43 Ashley, Ibid.; See also Jurgen Habermas, Knowledge and Human Interests, Boston MA, Beacon Press, 1971.

44 Hutchings, Ibid., p. 75.

45 Hutchings, Ibid., p. 75. 
Table I. A Possible Critical Theory Research Agenda For Religion And IR Theory

CT Arguments "Theory is always for someone and for
some purpose."

If history is produced by our actions, then it should also be open to change. ${ }^{2}$
Possible Religion/IR Theory Research Questions

If theory serves the values of certain actors, then which and whose values does the ignorance of religion in IR theory serve to?

If the history of IR is made in a way to exclude religions' impact on international politics, then is it possible to see and read it differently? If possible, then how could one offer a 'potential for progress' immanent within it?

Does the so-called 'dominance' of positivism in IR theory produce a system of inclusion/exclusion in theorizing?

If positivism is understood as a system of inclusion/ exclusion and as a major reason behind 'areligious' IR theory, Can discourse ethics open up new ways in IR theory to study religion?

Structural realism's 'technical interest' in control has come to dominate classical realism's 'practical interest' of understanding during the Cold war. A reflective version of Structural Realism (Technical Realism) is needed. ${ }^{4}$
Can (or should) reflective versions of Realism analyze the role of religion international politics? Should religion be incorporated within it?

Table 1 summarizes the main claims of the study so far, by identifying four significant assumptions of Critical Theory and how they can help raising research questions to integrate religion into the theory of IR. We argue that, once answered, these questions have a strong potential to provide a way towards integrating religion into the theoretical analysis in IR. Yet rather than arguing that Critical Theory is the one and only tool for an IR theory considering religion, we offer it as a potential power that is imminent in IR theory to reduce its ignorance of religion. "There is ... no such thing as theory in itself, divorced from a standpoint in time and space. When any theory so represents itself, it is more important to examine it as ideology, and to lay bare its concealed perspective" 46 . This is the main criticism that Cox directed against problem-solving theories. However it is important to note that this criticism and rejection of the problem solving 
theories has also counterproductive effects on the feasibility of critical theories. Critical theories, by explaining the political nature of theorizing and the production/reproduction of structures that create inequalities and exclude some (especially weak, poor and/or powerless) segments of the human society have mainly rejected problem-solving theories. In other words, they have focused on showing the historical process, the process of theorizing and emphasized the need for an emancipatory change in the future. However, while making the diagnosis critical theories have generally remained without giving the treatment. They have shown, for instance, that a change towards emancipation is both possible and necessary but because of their attempt of differentiating their theories from problem-solving theories they did not show how emancipation for all segments, moral-stand points, or bounded communities is to be achieved. That is to say, they show the problem but do not solve it. So, while criticizing the systems of exclusion, critical theories do not provide any way to overcome and change it.

\section{Conclusion}

The development of a 'positive' science understanding, represented by a belief in human rationality and human capacity to reason, has been a major factor behind the denial or ignorance of metaphysics in the explanation of social and natural phenomena. Such an understanding of science brought with it a certain methodology, enthusiastic for -if not obsessed withexperimentation and observation. This enthusiasm was followed by the idea of 'secularism in science, which in its broadest sense refers to the separation of religious explanation from scientific explanation. The idea of secularism has had important effects on the development of science in general and disciplines like IR in particular. This study focuses on the sources of the taken-forgranted secularism in mainstream IR theory and aims to propose an alternative research direction that could incorporate religion in theorizing.

John Stuart Mill ${ }^{47}$ in his introduction to August Comte and Positivism makes a somewhat ironic comment about peoples' understanding of positivist claims: "It is not very widely known what they represent, but it is understood that they represent something." The same comment is also true for the term 'secularism'. It is easy to define it broadly and to argue that it refers to the separation of religion from 'something'. To make an analogy with Mill's comment on positivism: it is difficult to define what kind of a 'separation' the term refers to but people know that it refers to a 'separation'. Analyzing the impact of the term becomes even more complicated when one thinks whether such separation is 'necessary' or even 'possible'. Such complexity continues when one analyzes IR theory. Studies on the IR theory literature clarify that, either intentionally or not, IR scholars have seen 'secularism' in IR as both necessary and possible. The separation seems to have led IR theory scholars ignore religion. This study tracked down the reasons behind such ignorance. Then, offers a possible Critical Theory research agenda to overcome what we call an intellectual failure. 
Since the 1981 articles of Cox and Ashley, critical studies have made themselves heard in the discipline and have evolved in two directions. Some of the critical theorists have followed the neo-Marxian analysis of Cox whereas others moved towards post-modernism and poststructuralism with an emphasis on discourse, social learning, and production/reproduction of certain social structures. Some have used both ways to develop a critique of the mainstream approaches. One of the main points that most of the critical approaches have in common is the rejection of what they called 'problem-solving' theories. Critical theories do differentiate themselves from problem-solving theories in a number of ways. First, as explained above critical theories claim that theorizing is a political act; thus, theories cannot be objective or value free. In this sense, as Hobson ${ }^{48}$ mentions, Critical Theory is 'self-reflexive' and most of the critical theorists are "aware of their own values and biases". Second, Critical Theory refuses problemsolving theories' 'ahistoricism' and, as it is also mentioned above, proposes a historical analysis to reveal the potential for change. In other words, according to critical theory history is diagnosed and it is 'made.' The potential for change is immanent within it and this potential can only be revealed with historicism. Once historicism is accepted, then the potential for change can be identified and accordingly transformation towards an emancipatory future can be achieved ${ }^{49}$.

The introduction of Critical Theory within the IR discipline contains prospects to develop theoretical arguments to overcome the ignorance. A set of research questions for a possible Critical Theory research on religion and IR theory has been provided above. But such perspective, of course, did not go without criticism. It is argued that, referring that something is to be changed is different from proposing ways to change it. This, in fact, is an important obstacle over the feasibility of critical theories. This is one of the main criticisms that could be directed at critical theories.

Finally, the main point can be clarified when such critical questions are asked with reference to religion and IR. Whose values, for instance, did IR theory serve for? And for which purposes did it do so? Can bringing religion back in IR theory be defined in terms of an emancipation? Would it mean that the voices of those people (take Muslims for instance) who are silenced within the academic literature or in world politics be heard? Critical theory helps us ask these questions in detail and with different combinations but it is not that helpful in terms of answering them. 


\section{References}

ASHLEY, Richard K. “Political Realism and Human Interest”, International Studies Quarterly, 1981, 25, p. 204-236.

BULL, Hedley, "International Theory: The Case for a Classical Approach", World Politics, 1966, 18(3), p. 361-377.

BURTT, E. A., The Metaphysical Foundations of the Modern Science, New York, Dover Publications, 2003.

COX, Robert, “Social Forces, States and World Orders: Beyond International Relations Theory”, Millennium: Journal of International Studies, 1981, 10(2), p. 126-55.

FOX, Jonathan, The Multiple Impacts of Religion on International Relations: Perceptions and Reality in Religion and International Relations, 2006, http://www.cairn-int.info/article-E_PE_064_1059-the-multiple-impacts-of-religion-on.htm (03.09.2015).

FOX, Jonathan and Shmuel Sandler, Bringing Religion into International Relations, New York, PalgraveMacmillan, 2004.

GÜNER, Serdar, "Religion and Preferences: A Decision-theoretic Explanation of Turkey's New Foreign Policy", Foreign Policy Analysis, 2012, 8(3): 217-230.

GRIFFITHS, M., S. C. Roach, and M. S. Solomon, Fifty Key Thinkers in International Relations, London, Routledge, 2009.

HABERMAS, Jurgen, Knowledge and Human Interests, Boston MA, Beacon Press, 1971.

HABERMAS, Jurgen, Moral Consciousness and communicative Action, Cambridge, Polity, 1990.

HABERMAS, Jurgen, Justification and Application: Remarks on Discourse Ethics, Cambridge, MIT Press, 2001.

HANNAM, James, God's Philosophers: How the Medieval World Laid the Foundations of the Modern Science, London, Icon Books, 2009.

HURD E. S., “The Political Authority of Secularism in International Relations", European Journal of International Relations, 2004, 10(2): p. 235-62.

HUTCHINGS, Kimberly, "Happy Anniversary! Time and Critique in International Relations Theory", Review of International Studies, 2007, 33, p. 71-89.

HOBSON, John M. "Is critical theory always for the white west and western imperialism? Beyond Westphalian towards a post-racist critical IR", Review of International Studies, 2007, 33, p. 91116.

KAPLAN, Morton A. “The New Great Debate: Traditionalism vs. Science in International Relations”, World Politics, 1966, 19(1), p. 1-20.

MILL, John Stuart, Auguste Comte and Positivism, London, N. Trübner, 1865.

PHILPOTT, D. “The Challenge of September 11 to Secularism in International Relations”, World Politics, 2002, 55(1), p. 66-95.

LAUSTSEN C. B. and Ole Waever, "In Defense of Religion: Sacred referent Objects for Securitization", Millennium, 2000, 29(3), p. 705-739.

LINKLATER, Andrew, “The Achievements of Critical Theory”, International Theory, Eds: S. Smith, K. Booth, and M. Zalewski, Cambridge, Cambridge University Press, 1996, p. 279-298.

RENGGER, Nicholas and Ben Thirkel-White, "Still Critical After all These Years? The Past the Present and Future of Critical Theory in International Relations", Review of International Studies, 2007, 33, p. 3-24.

SANDAL, Nükhet Ahu and Jonathan Fox, Religion in International Relations Theory: Interactions and Possibilities, New York, Routledge, 2013.

SANDAL, Nükhet Ahu and Patrick James, "Religion and International Relations Theory: Towards a Mutual 
Understanding", European Journal of International Relations, 2011, 17(1), p. 3-25.

SNYDER, Jack, Religion and International Relations Theory, New York, Columbia University Press, 2012. 